\title{
KETERKAITAN MANAGERIAL OWNERSHIP DAN LEVERAGE TERHADAP NILAI PERUSAHAAN: DALAM KONTEK HUBUNGAN KEAGENAN PERUSAHAAN DI INDONESIA
}

\author{
Margarita Ekadjaja ${ }^{1 *}$, Rorlen$^{2}$, Fanny Andriani Setiawan ${ }^{3}$, Kartika Nuringsih ${ }^{4}$ \\ ${ }^{1}$ Jurusan Manajemen, Universitas Tarumanagara Jakarta \\ Email :margaritae@fe.untar.ac.id \\ ${ }^{2}$ Jurusan Manajemen, Universitas Tarumanagara Jakarta \\ Email : rorlen@fe.untar.ac.id \\ ${ }^{3}$ Jurusan Akuntansi, Universitas Tarumanagara Jakarta \\ Email : fannys@fe.untar.ac.id \\ ${ }^{4}$ Jurusan Manajemen, Universitas Tarumanagara Jakarta \\ Email : kartikan@fe.untar.ac.id \\ *penulis korespondensi
}

\begin{abstract}
ABSTRAK
Manajemen dan nilai perusahaan memiliki keterkaitan yang tidak dapat dipisahkan. Dimana manajemen perusahaan merupakan penggerak roda perusahaan dan berorientasi pada nilai perusahaan. Peran seorang manajer adalah memaksimalkan kekayaan bagi pemegang saham. Namun, manajer yang tidak memiliki kepemilikan saham yang signifikan di perusahaan dapat memilih untuk memaksimalkan keuntungan bersih mereka sendiri dengan mengorbankan pemilik perusahaan. Akibatnya, pemilik terpaksa mengeluarkan biaya agensi untuk memastikan bahwa manajemen perusahaan bertindak dengan cara yang tepat. Cara untuk mengurangi biaya agensi adalah memaksa perusahaan untuk meningkatkan hutang. Tujuan penelitian adalah menguji hubungan simultan pertukaran antara ownership, leverage, dan nilai perusahaan sehubungan dengan keagenan pada perusahaan manufaktur di Indonesia dari tahun 2012-2018. Penelitian ini menambah pemahaman mengenai keterkaitan antara ownership dengan leverage, dan nilai perusahaan. Analisis data untuk argumen tentang keterkaitan simultan antara ownership, leverage, dan nilai perusahaan melalui data panel regresi berganda 2 SLS (Two Stage Least Square). Bidang penelitian ini diperluas dengan mempertimbangkan model empiris di mana ownership dan leverage masing-masing diperlakukan sebagai variabel endogen atau ditentukan bersama. Dalam metode 2 SLS ada 2 kali variabel yang diobservasi secara simultan untuk menghindari bayes sehingga variabel tersebut tidak bias, di mana variabel managerial ownership dan Leverage merupakan determinan non linier nilai perusahaan sebagai bagian integral dari pengambilan keputusan perusahaan dalam kerangka keagenan. Persamaan Regresi hasil uji 2SLS memunjukkan keterkaitan nilai perusahaan dengan managerial ownership dan leverage. Hasil menunjukkan interaksi positif tidak signifikan antara managerial ownerhip dengan nilai perusahaan, interaksi positif signifikan antara nilai perusahaan dengan leverage, dan interaksi yang negatif signifkan antara managerial ownership dengan leverage.
\end{abstract}

Kata Kunci : ownership, leverage, nilai perusahaan, biaya agensi

\begin{abstract}
Management and corporate value have an inseparable relationship. Where the company management is the driving force of the company and oriented to corporate values. The role of a manager is to maximize wealth of shareholders. However, managers who do not have a significant share in the company may choose to maximize their own net profits at the expense of the company owners. As a result, the owners are forced to incur agency costs to ensure that company management acts in an appropriate manner. The way to reduce agency costs is to force the company to increase debt. The research objective is to examine the exchange simultaneous relationship between ownership, leverage, and corporate value with respect to agency in manufacturing companies in Indonesia from 2012-2018. This study adds to the understanding of the relationship between ownership and leverage, and corporate value. Data analysis for arguments about the simultaneous relationship between ownership, leverage, and firm value through 2 SLS (Two Stage Least Square) multiple regression panel data. This field of research is extended by considering empirical models in which ownership and leverage are treated as endogenous or codetermined variables, respectively. Ownership and Leverage as an integral part of corporate decision making within an agency framework, which in turn will affect the value of the company. In the SLS 2 method, there are 2 variables that are observed simultaneously to avoid bayes so that the variable is not biased, in which the
\end{abstract}


managerial ownership and leverage variables are nonlinear determinant corporate value as an integral part of corporate decision making within the agency framework, which in turn will affect firm value. The 2SLS regression equation results show the relationship between firm value and managerial ownership and leverage. The results prove that there is a positive interaction between managerial ownership between firm value, a significant positive interaction between firm value and leverage, and a significant negative interaction between managerial ownership and leverage.

Keywords: Ownership, Leverage, Company Value, Agency Costs

\section{PENDAHULUAN}

\section{Latar Belakang}

Peran seorang manajer adalah memaksimalkan kekayaan pemegang saham. Namun, manajer yang tidak memiliki kepemilikan saham yang signifikan di perusahaan dapat memilih untuk memaksimalkan keuntungan bersih mereka sendiri dengan mengorbankan pemilik perusahaan. Akibatnya, pemilik terpaksa mengeluarkan biaya agensi untuk memastikan bahwa manajemen perusahaan bertindak dengan cara yang tepat. Masalah penting bagi pemegang saham perusahaan adalah mengetahui cara membujuk manajemen membuat keputusan yang memaksimalkan kekayaan pemegang saham sambil meminimalkan biaya agensi. Salah satu kemungkinannya adalah memberi manajemen perusahaan suatu kepemilikan saham yang signifikan di perusahaan.

Menurut Sinha \& Agnihotri (2015) nilai dari perusahaan (nilai perusahaan) yang terdaftar di bursa dapat dijadikan rujukan dalam setiap transaksi adalah nilai kapitalisasi pasar. Saat manajemen perusahaan dikelola sendiri oleh managerial ownership, maka manajer akan juga termotivasi untuk memperkaya diri sendiri. Menurut Zhang, et. al (2018) walaupun kepemilikan sham individual cukup besar, namun kepemilikan investor institusional terus meningkat, sehingga keputusan investor individual akan terpengaruh. Tidak jarang investor institusional melakukan pendekatan kepada investor individual, sehingga managerial ownership yang merupakan wakil dari investor institusional dapat melakukan intervensi.

Menurut Boshkoska (2014) perusahaan besar yang memecat agennya (manajer) sangat kecil kemungkinannya. Situasi ini disebabkan kepemilikan perusahaan sangat tersebar, dan proteksi mekanisme control sangat kuat, sehingga hampir tidak mungkin ada pemegang saham yang tidak sepakat dengan keputusan yang dilakukan manajer. Manajer yang dapat memaksimalkan harga saham, tentu akan dapat bekerja secara otonomi serta memperoleh insentif yang besar. Mekanisme monitoring yang dapat dilakukan untuk mengurangi masalah agensi di perusahaan antara lain melalui : pengawasan oleh dewan komisaris independen, memperkecil free cash flow, dan meningkatkan institusional ownership (Iqbal, et.al., 2020). Hasil penelitian Ekadjaja, et al. (2019) dan Susanto (2020) menunjukan adanya implikasi antara managerial ownership dengan nilai perusahaan, Sulong, et.al (2013) membuktikan efek negatif kepemilikan terhadap kinerja perusahaan.

Penelitian ini melengkapi studi Crutchley \& Hansen (1989) mengenai uji teori keagenan dalam menentukan hubungan kepemimpinan manjerial, tingkat utang dan dividen perusahaan. Variabel penelitian berbeda sehingga dapat diamati seberapa besar pengaruh dari variabel-variabel lain, meliputi managerial ownership, institusional ownership, foreign ownership, leverage, dividen, dan firm size terhadap nilai perusahaan secara serentak. Kontribusi dari penelitian ini antara lain: Pertama, pemodelan sistem tiga persamaan secara bersamaan yang secara eksplisit managerial ownership, leverage, dan nilai perusahaan. Kedua model penelitian ini memungkinkan untuk lebih memahami menggunakan metode 2 SLS untuk menguji model persamaan secara simultan. 


\section{Rumusan Masalah}

Dampak struktur kepemilikan perusahaan dan ketergantungan variabel seperti kinerja perusahaan atau pembayaran hutang terlihat pada hasil penelitian (Susan, 2018), namun bukti empiris dan analitis dari struktur kepemilikan dan kebijakan dividen sebagai tambahan penentu struktur pemodalan perusahaan masih kurang, terutama di negara berkembang seperti Indonesia. Penelitian ini menambah pemahaman mengenai keterkaitan antara ownership dengan leverage, dan nilai perusahaan. Analisis data untuk argumen tentang keterkaitan antara ownership, leverage, dan nilai perusahaan menggunakan panel 2 SLS (Two Stage Least Square). Metode 2 SLS cocok untuk variabel endogennya bersifat nonlinier (Chen \& Steiner, 1999) dimana 1 estimator suatu parameter memperhitungkan standard error setiap estimator (Gujarati \& Gujarati, 2015).

Bidang penelitian ini diperluas dengan mempertimbangkan model empiris di mana ownership dan leverage masing-masing diperlakukan sebagai variabel endogen atau ditentukan bersama. Ownership dan Leverage sebagai bagian integral dari pengambilan keputusan perusahaan dalam kerangka keagenan, yang pada akhirnya akan mempengaruhi nilai perusahaan.

Dengan dasar pengujian pada agency theory, maka identifikasi rumusan masalah sebagai berikut:

1. Apakah ada keterkaitan antara managerial ownership dengan nilai perusahaan?

2. Apakah ada keterkaitan antara leverage dengan nilai perusahaan ?

3. Apakah ada keterkaitan antara leverage dengan managerial ownership ?

Berikut gambar kerangka pemikiran penelitian yang menjelaskan perumusan hipotesis :

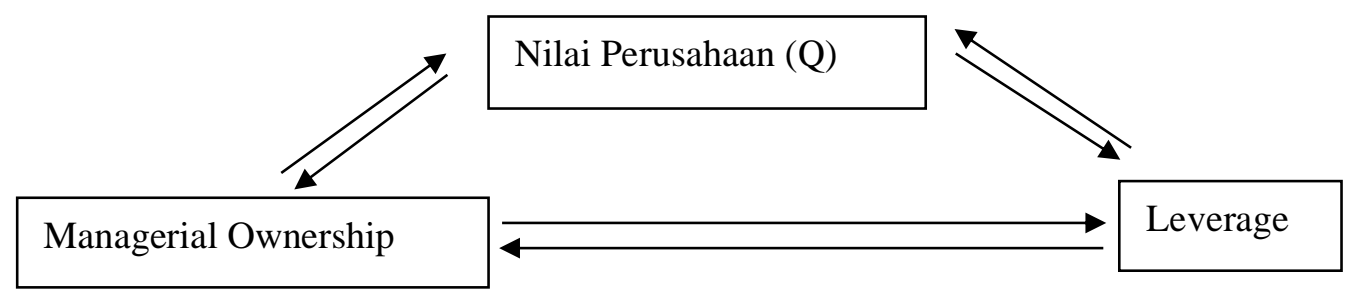

Gambar 1. Model Penelitian

Sumber Gambar : Penulis (2021)

Gambar 1. Model Penelitian menunjukkan bahwa adanya keterkaitan antara nilai perusahaan, managerial ownership, dan leverage. Di mana managerial ownership dapat memotivasi manajer supaya merasa sebagai pemilik perusahaan sehingga akan berhati-hati dalam mengambil keputusan. Menurut Henny \& Sha (2020), kepemilikan manajerial dan kepemilikan institusional berpengaruh signifikan terhadap future earnings response coefficient dengan pertumbuhan perusahaan sebagai variabel mediasi. Sementara leverage (keputusan perusahaan menggunakan utang) merupakan sumber dana perusahaan yang mendorong kinerja perusahaan maka ditempatkan simultanitas dalam rangka membantu nilai perusahaan. Hatem (2015) menemukan adanya ketergantungan antara managerial ownership dengan nilai perusahaan. Sementara Safitri \& Wulanditya (2019) menemukan adanya pengaruh antara kepemilikan manajerial, kepemilikan institusional, dan arus kas terhadap peningkatan nilai perusahaan. Yegon, et.al (2014) menemukan bahwa peningkatan pada kepemilikan institusional menyebabkan penurunan pada biaya keagenan, karena pihak institusional dapat mengontrol perilaku manajer dalam mengambil keputusan sehingga kinerja perusahaan meningkat. Peningkatan kinerja perusahaan akan berakibat pada peningkatan nilai perusahaan. Lee \& Chung (2018) menemukan bahwa 
peningkatan pada foreign ownership dapat meningkatkan likuiditas saham yang pada akhirnya dapat meningkatkan nilai perusahaan.

Hasil penelitian Susanto (2020) menunjukkan managerial ownership, institutional ownership, dividend policy, dan firm size berpengaruh positif and signifikan terhadap kinerja perusahaan. Anton (2017) menemukan adanya pengaruh dari leverage terhadap nilai perusahaan, dengan menggunakan sampel data pada perusahaan yang terdaftar di bursa Rumania pada periode 2001 2011 dan variabel kontrol antara lain pertumbuhan sales, pertumbuhan asset, dan pertumbuhan tenaga kerja. Hasil dari model regresi efek tetap menunjukan bahwa leverage memiliki pengaruh positif terhadap nilai perusahaan. Dalam penelitian ini, institusional ownership dan dividen digunakan sebagai variabel kontrol nilai perusahaan.

Perumusan hipotesis pertama penelitian :

\section{H1 : Adanya keterkaitan secara positif managerial ownership terhadap nilai perusahaan}

H2 : Adanya keterkaitan secara positif leverage terhadap nilai perusahaan

Pratama \& Wiksuana (2016) menemukan bahwa ukuran perusahaan berpengaruh positif terhadap nilai perusahaan, dimana perusahaan yang berukuran besar cenderung berani menerbitkan saham sehingga mendapatkan kepercayaan dari manajerial untuk menjadi investor (institusi maupun foreign) perusahaan tersebut. Menurut Puspitowati, et.al (2018), kesulitan dalam keuangan menyebabkan perusahaan mengubah keputusan penggunaan utang, di mana perusahaan lebih mendahulukan menambah utang daripada menambah ekuitas. Bamiatzi, et.al (2017) menemukan dengan leverage yang rendah menyebabkan risiko perusahaan rendah dan secara tidak langsung akan mempengaruhi kepemilikan saham manajerial. Sumartha (2016) menemukan adanya pengaruh antara managerial ownership terhadap kebijakan dividen perusahaan. Pada institusional ownership dimana perusahaan yang tidak memiliki managerial ownership menyebabkan pengaruhnya terhadap kebijakan dividen adalah negatif (berlawanan arah). Variabel kontrol yaitu profitabilitas dan firm size memiliki pengaruh positif signifikan terhadap kebijakan dividen perusahaan. Dalam penelitian ini, Firm Size dan foreign ownership merupakan variabel kontrol dari managerial ownership. Perumusan hipotesis ke tiga penelitian adalah :

\section{H3 : Adanya keterkaitan secara negatif leverage terhadap managerial ownership.}

Model persamaan simultan dalam penelitian diestimasi menggunakan metodologi Two stage least squares (2SLS).

Berikut merupakan model persamaan penelitian:

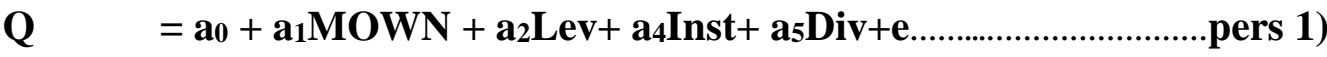

$$
\begin{aligned}
& \text { Lev }=b_{0}+b_{1} Q+b_{2} M O W N+b_{3} D i v+b 4 \text { Size+e...............................pers 2) }
\end{aligned}
$$

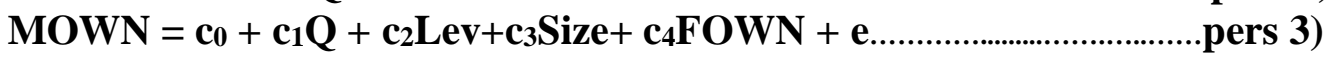

Di mana :

$\mathrm{Q} \quad=$ Nilai perusahaan

MOWN = Managerial Ownership

INST = Institutional ownership, merupakan variabel kontrol Q

FOWN = Foreign ownership, merupakan variabel kontrol MOWN

Lev = Leverage

Div = Dividen sebagai variabel kontrol terhadap Q dan LEV

Size = Firm Size sebagai variabel control terhadap LEV dan MOWN 
Model persamaan tersebut menggambarkan keterkaitan antar variabel penelitian secara simultan di mana seluruh persamaan model penelitian adalah overidentified. Metode yang digunakan adalah 2 SLS karena jika penaksiran parameter menggunakan metode OLS (Ordinary Least Square) pada setiap persamaan tanpa memperhatikan keterkaitan model persamaan maka pengukuran hubungan antar variabel menjadi bias.

\section{METODE PENELITIAN}

Populasi dalam penelitian ini berdasarkan laporan keuangan perusahaan manufaktur yang terdaftar di Bursa Efek Indonesia yang memiliki data managerial ownership periode 2012-2018. Pemilihan sampel menggunakan metode purposive sampling. Berdasarkan kriteria diperoleh 100 perusahaan manufaktur yang memenuhi, sehingga total data penelitian sebanyak 700 observasi. Variabel dalam penelitian ini terdiri atas : 3 variabel dependen yaitu nilai perusahaan yang diukur dengan Tobin $\mathrm{Q}(\mathrm{Q})$, managerial ownership dan leverage. Sementara foreign ownership dan institutional ownership merupakan variabel kontrol terhadap Q. Demikian juga firm size sebagai variabel kontrol pada persamaan managerial ownership.Metode pengolahan data menggunakan 2SLS (Two Stage Least Square) melalui aplikasi Eviews 6.0. Chen \& Steiner (1999) menggunakan 2SLS non-linier untuk memperkirakan dampak kepemilikan terhadap kebijakan utang dan kebijakan dividen. Penggunaan 2SLS menguntungkan, memberikan perkiraan yang konsisten dan tidak bias asimtotik dengan adanya variabel yang ditentukan secara bersamaan. Seperti OLS (ordinary Least Square), 2SLS menghasilkan hasil yang konsisten dengan adanya bias simultan. Metode 2SLS lebih disukai daripada metode kuadrat terkecil biasa (OLS) karena metode terakhir mengarah pada perkiraan parameter yang bias dan tidak konsisten ketika sistem memiliki variabel endogen yang saling bergantung.

Dalam penelitian ini rasio managerial ownership, rasio leverage, dan rasio nilai perusahaan merupakan variabel endogen ke sistem. Selama sistem persamaan ditentukan dengan benar dan berisi jumlah regresi yang berbeda di setiap persamaan, 2SLS memberikan perkiraan yang konsisten dan juga efisien. Melalui 2SLS memungkinkan kita untuk melihat bagaimana managerial ownership mempengaruhi nilai perusahaan terpisah dari bagaimana keputusan leverage mempengaruhi managerial ownership. Ini dilakukan dengan memisahkan hasil ke dalam proses keputusan yang berbeda, atau persamaan perkiraan.

Pengujian order dan rank condition dilakukan untuk mengidentifikasi persamaan simultan dalam penelitian sebagai berikut :

1. Pengujian order model persamaan dikatakan over identified jika $(\mathrm{K}-\mathrm{k})>(\mathrm{m}-1)$, dimana

$\mathrm{K}=$ Jumlah seluruh variabel dalam model simultan

$\mathrm{k}=$ Jumlah variabel eksogen dalam suatu persamaan

$\mathrm{m}=\mathrm{Jumlah}$ model persamaan

$\mathrm{Q}=\alpha+\beta \mathrm{MOWN}+\beta \mathrm{Lev}+\beta$ Inst $+\beta$ Div $+\mathrm{e}$

$(\mathrm{K}-\mathrm{k})>\mathrm{m}-1$

$(7-4)>3-1$

$3>2$ (over identified)

Lev $=\alpha+\beta \mathrm{Q}+\beta \mathrm{MOWN}+\beta \mathrm{Div}+\beta \mathrm{Size}+\mathrm{e}$

pers 2)

$(\mathrm{K}-\mathrm{k})>\mathrm{m}-1$

$(7-4)>3-1$

$3>2$ (over identified)

$\mathrm{MOWN}=\alpha+\beta \mathrm{Q}+\beta \mathrm{Lev}+\beta \mathrm{Size}+\beta \mathrm{FOWN}+\mathrm{e}$

$(\mathrm{K}-\mathrm{k})>\mathrm{m}-1$ 
$(7-4)>3-1$

$3>2$ (over identified)

2. Rank Condition, di mana suatu model simultan dapat menggunakan metode 2SLS jika paling sedikit 1 determinan $\neq 0$, dengan matriks order $\mathrm{M}-1$, di mana $\mathrm{M}$ adalah jumlah variabel endogenous variable, sehingga dalam penelitian ini matriks order-nya adalah $2 \times 2$

Matriks persamaan simultan dalam penelitian sebagai berikut :

\begin{tabular}{ccccccccc}
\hline Persamaan & C & Q & MOWN & LEV & FOWN & INST & DIV & SIZE \\
\hline 1 & $-\alpha$ & 1 & $-\beta 1$ & $-\beta 2$ & 0 & $-\beta 3$ & $-\beta 4$ & 0 \\
\hline 2 & $-\alpha$ & $-\beta 5$ & $-\beta 6$ & 1 & 0 & 0 & $-\beta 7$ & $-\beta 8$ \\
\hline 3 & $-\alpha$ & $-\beta 9$ & 1 & $-\beta 10$ & $-\beta 11$ & 0 & 0 & $-\beta 12$ \\
\hline
\end{tabular}

\begin{tabular}{|c|c|c|c|}
\hline Persamaan 1, diperoleh determinan matriks & 0 & $\begin{array}{l}-\beta 8 \\
-\beta 11\end{array}$ & $\begin{array}{l}\text {, Determinan } \neq 0 \\
-\beta 12\end{array}$ \\
\hline Persamaan 2, diperoleh determinan matriks & 0 & $\begin{array}{l}-\beta 3 \\
-\beta 11\end{array}$ & , Determinan $\neq 0$ \\
\hline Persamaan 3 , diperoleh determinan matriks & {$\left[\begin{array}{c}-\beta 3 \\
0\end{array}\right.$} & $\begin{array}{c}-\beta 4 \\
-\beta 7\end{array}$ & Determinan $\neq 0$ \\
\hline
\end{tabular}

Berdasarkan hasil pengujian order dan rank condition, maka model persamaan dalam penelitian dapat menggunakan metode 2SLS.

\section{HASIL DAN PEMBAHASAN}

Penelitian ini didesain untuk menganalisis keterkaitan managerial ownership dan leverage terhadap nilai perusahaan dalam kontek hubungan keagenan pada perusahaan di Indonesia. Orientasi penelitian ini adalah mengetahui keterkaitan simultan antara managerial ownership, leverage, dan nilai perusahaan di Indonesia. Managerial ownership dapat motivasi manajer supaya merasa sebagai pemilik perusahaan sehingga akan berhati-hati dalam mengambil keputusan dan Leverage merupakan sumber dana perusahaan yang mendorong kinerja perusahaan maka ditempatkan simultanitas dalam rangka membantu nilai perusahaan.

\begin{tabular}{lccccccc}
\hline & DPR_D & DPS & FOWN & INST & LEV & MO & SIZE \\
\hline DPR_D & 1.00000 & & & & & & \\
\hline DPS & 0.21216 & 1.00000 & & & & & \\
\hline FOWN & 0.09735 & 0.12172 & 1.00000 & & & \\
\hline INST & -0.07574 & 0.00924 & 0.25176 & 1.00000 & & \\
\hline LEV & -0.26050 & -0.13998 & -0.05399 & 0.12684 & 1.00000 & & \\
\hline MO & -0.14171 & -0.03096 & -0.05399 & -0.44763 & -0.05476 & 1.00000 & \\
\hline
\end{tabular}

Tabel 1. Uji Multikolinieritas

Sumber Tabel : Hasil Olah Data Penulis (2021) 


\begin{tabular}{llllllll}
\hline SIZE & 0.33156 & 0.25476 & -0.04690 & -0.13179 & 0.17504 & -0.06462 & 1.00000 \\
\hline
\end{tabular}

Tabel 1 menunjukkan dari hasil uji yang ada, dapat dikatakan bahwa variabel DPR_D, DPS, FOWN, INST, LEV, MO, dan SIZE tidak terjadi multikolinearitas karena memiliki nilai korelasi lebih kecil dari 0.8 kecuali variabel sendiri yang memiliki nilai korelasi lebih besar dari 0.8.

Tabel 2. Statistik Deskriptif

Sumber Tabel : Hasil Olah Data Penulis (2021)

\begin{tabular}{lccccccc}
\hline & $\mathrm{Q}$ & MOWN & LEV & INST & FOWN & DIV & SIZE \\
\hline Mean & 1.376790 & 0.163882 & 0.493323 & 0.648751 & 0.482749 & 0.541429 & 12.45025 \\
\hline Median & 1.017943 & 0.006500 & 0.486746 & 0.659450 & 0.535600 & 1.000000 & 12.52008 \\
\hline Maximum & 18.49091 & 2.910000 & 1.731100 & 0.979900 & 2.161900 & 1.000000 & 14.26907 \\
\hline Minimum & 0.163433 & 0.000000 & 0.062563 & 0.016300 & 0.000000 & 0.000000 & 10.15891 \\
\hline Std. Dev. & 1.346349 & 0.162992 & 0.215089 & 0.192260 & 0.266770 & 0.498637 & 0.811194 \\
\hline Observations & 700 & 700 & 700 & 700 & 700 & 700 & 700 \\
\hline
\end{tabular}

Berdasarkan Tabel 2. Statistik Deskriptif teridentifikasi bahwa probability atas Jarque-Bera dengan tingkat signifikansi 95\% $(\mathrm{a}=5 \%)$ maka variabel Q, MOWN, LEV, FOWN, INST, DIV dan SIZE terdistribusi secara normal dan nilai standar deviasinya lebih kecil dari nilai rataratanya. Hal ini menunjukkan bahwa penyimpangan data terhadap nilai rata-ratanya rendah, sehingga tidak terdapat data ekstrim yang dapat menimbulkan bias pada hasil penelitian. Ratarata nilai perusahaan 1,376790, hal ini mengimplikasikan bahwa manajerial perusahaan manufaktur di Indonesia dapat mengelola sumber dan pengeluaran perusahaan secara efektif sehingga nilai perusahaan lebih besar dari 1. Nilai standar deviasi sebesar 1,346349 menunjukkan penyimpangan pengukuran nilai perusahaan dan berdasarkan data laporan keuangan perusahaan manufaktur di Indonesia dari tahun 2012-2018 ada perusahaan yang nilai perusahaannya rendah, yaitu sebesar 0,163433. Rata-rata managerial ownership sebesar 0,062882 menunjukkan rata-rata persentase kepemilikan saham manajerial (Managerial Ownership) untuk memotivasi manajer yang bertindak sebagai pemilik dalam mengambil keputusan secara hati-hati hanya sebesar 6,2882\%. Hal ini menunjukkan masih sedikit perusahaan manufaktur di Indonesia terutama pada tahun 2012-2018 yang menawarkan kepemilikannya kepada para manajer, hal ini ditunjukkan dengan nilai minimum sebesar 0,000000. Rata-rata Lev (leverage) sebesar 0,493323 menunjukkan bahwa rata-rata tingkat leverage perusahaan manufaktur di Indonesia dari tahun 2012-2018 sebesar 49,3323. Hal ini menunjukkan bahwa perusahaan manufaktur di Indonesia cenderung menambah debt (utang) daripada ownership (menerbitkan saham). FOWN sebagai variabel kontrol dari managerial ownership memiliki nilai rata-rata sebesar 0,482749 menunjukkan rata-rata persentase kepemilikan saham asing (foreign ownership) sebesar 48,2749\%. INST sebagai variabel kontrol dari nilai perusahaan memiliki rata-rata sebesar 0,648751 menunjukkan rata-rata persentase kepemilikan saham institusi sebesar 64,8751. Div sebagai variabel kontrol nilai perusahaan dan leverage memiliki rata-rata sebesar 0,541429 menunjukkan rata-rata persentase perusahaan yang membagikan dividen sebesar 54,1429\%. Dengan nilai maksimum 1,000000 dan nilai minimum 0,000000. Nilai minimum Div 0 menunjukkan antara tahun 2012 dan tahun 2018 ada perusahaan manufaktur di Indonesia yang tidak membagikan dividen. Rata-rata Size sebagai variabel kontrol leverage dan managerial ownership sebesar 12,45025 dan nilai standar deviasi sebesar 0.811194, menunjukkan bahwa tingginnya nilai kapitalisasi pasar. Dengan nilai maksimum 14,26907 juta Rupiah dan nilai minimum 10,15891 juta Rupiah. 

NILAI PERUSAHAAN: DALAM KONTEK HUBUNGAN KEAGENAN PERUSAHAAN DI INDONESIA

Tabel 3. Hasil Uji 2SLS

Sumber Tabel : Hasil Olah Data Penulis (2021)

\begin{tabular}{|c|c|c|c|}
\hline & $\mathrm{Q}$ & LEV & MOWN \\
\hline $\mathrm{C}$ & $\begin{array}{l}0,701941 \\
(0,0065)^{*}\end{array}$ & $\begin{array}{l}1.080579 \\
(0.2721)\end{array}$ & $\begin{array}{l}0.264199 \\
(0.0081)^{*}\end{array}$ \\
\hline \multirow[t]{2}{*}{ MOWN } & 0.469205 & -0.223057 & - \\
\hline & $(0.1846)$ & $(0.0624)^{* * *}$ & \\
\hline \multirow{2}{*}{ LEV } & 0,776172 & - & -0.036420 \\
\hline & $(0.0016)^{*}$ & & $(0.2117)$ \\
\hline \multirow[t]{2}{*}{ INST } & 0,093753 & - & - \\
\hline & $(0.7530)$ & & \\
\hline \multirow[t]{2}{*}{ DIV } & 0,372382 & $-0,159885$ & - \\
\hline & $(0.0005)^{*}$ & $(0.0000)^{*}$ & \\
\hline \multirow[t]{2}{*}{ FOWN } & - & - & -0.015350 \\
\hline & & & $(0.5115)$ \\
\hline \multirow[t]{2}{*}{ SIZE } & - & -0.071138 & -0.014858 \\
\hline & & $(0.4729)$ & $(0.0668)^{* *}$ \\
\hline Q & & $\begin{array}{l}0.289824 \\
(0.1258)\end{array}$ & $\begin{array}{l}0.006574 \\
(0.1761)\end{array}$ \\
\hline
\end{tabular}

Tabel 3. Persamaan Regresi menunjukkan hasil uji 2SLS membuktikan adanya interaksi yang positif namun tidak signifikan antara managerial ownership dengan nilai perusahaan, sehingga hipotesis pertama (H1) diterima. Hasil uji 2 SLS juga menemukan adanya interaksi yang positif signifikan yaitu variabel leverage terhadap nilai perusahaan dengan nilai $p$ sebesar 0,0016 , sehingga hipotesis dua $(\mathrm{H} 2)$ diterima. Berdasarkan nilai tersebut, dapat dikatakan bahwa variabel kontrol yang memperkuat pengaruh antara leverage terhadap nilai perusahaan adalah dividen akan berpengaruh signifikan. Pengaruh dividen terhadap nilai perusahaan adalah positif signifikan sebesar 0,372382 dengan nilai $\mathrm{p}$ sebesar 0,0005 . Sementara pengaruh dividen sebagai variabel kontrol leverage berpengaruh negatif signifikan yaitu sebesar - 0,159885 dengan nilai $\mathrm{p}$ sebesar 0 .

Hasil Uji 2SLS juga menunjukkan adanya keterkaitan antara managerial ownership terhadap leverage yang negatif signifikan, sehingga hipotesis tiga $(\mathrm{H} 3)$ diterima. Ukuran perusahaan (Size) sebagai variabel kontol managerial ownership (MOWN) berpengaruh negatif signifikan yaitu sebesar 0,014858 dan nilai p sebesar 0,0668. Variabel managerial ownership memperkuat pengaruh signifikan interaksi antara leverage dengan nilai perusahaan, dan variabel kontrol dividen justru memperkuat positi interaksi antara leverage dengan nilai perusahaan. Nilai probability merupakan nilai yang diperhatikan dalam melakukan uji secara parsial (uji t). Penelitian ini menggunakan tingkat keyakinan sebesar 95\%. Nilai probability $<0,05$ menunjukkan bahwa $\mathrm{H}_{0}$ diterima.

Hasil dari persamaan simultaneous managerial ownership, leverage, dan nilai perusahaan menunjukkan adanya keterkaitan antara managerial ownership dan leverage terhadap nilai perusahaan. Di mana keterkaitan antara leverage terhadap nilai perusahaan adalah positif signifikan, artinya jika nilai leverage meningkat maka nilai perusahaan akan meningkat. Hasil penelitian sejalan dengan penelitian Anton (2017) dan konsep teori dalam menghitung nilai perusahaan dimana besarnya kewajiban (leverage) akan menambah nilai perusahaan (Q). Sementara keterkaitan antara leverage dengan managerial ownership adalah berlawanan arah, artinya jika tingkat hutang perusahaan meningkat menyebabkan kepemilikan manajerial tersebut menurun. Pernyataan ini sejalan dengan Jensen \& Meckling (1976) yang menyatakan bahwa 
hutang perusahaan dan managerial ownership bertindak sebagai solusi untuk mengendalikan konflik agensi dan pada akhirnya akan berpengaruh kepada nilai perusahaan. Dalam hal ini, persentase managerial ownership yang lebih tinggi dapat memitigasi biaya agensi dengan menyelaraskan kepentingan manajer dan pemegang saham (Lee \& Kuo, 2014).

Managerial ownership merupakan faktor untuk penggunaan sumber daya perusahaan yang lebih baik dan mengurangi biaya agensi (Rashid, 2016). Managerial Ownership cenderung menyelaraskan kepentingan manajer dan pemegang saham dan mengurangi konflik agensi. Berkaitan dengan hal tersebut, Rashid (2016) mengemukakan bahwa konvergensi kepentingan terjadi pada tingkat kepemilikan tertentu, karena adanya hubungan nonlinier Managerial Ownership dan agency cost. Hasil dari persamaan simultaneous managerial ownership terhadap leverage menunjukkan adanya interaksi berlawanan arah, yang artinya semakin banyak kepemilikan manajerial maka tingkat leverage menjadi rendah. Dividen sebagai variabel kontrol dari leverage, dan nilai perusahaan berpengaruh signifikan terhadap simultaneous leverage, dan nilai perusahaan. Hal ini disebabkan karena dividen adalah kebijakan perusahaan dalam mempertahankan laba perusahaan dan berfungsi untuk mengurangi biaya agensi, perusahaan akan menetapkan pembayaran dividen yang lebih tinggi ketika manajer memegang bagian yang lebih rendah dari ekuitas.

Pengaruh firm size terhadap managerial ownership berpengaruh negatif signifikan yang mempengaruhi keterkaitan antara managerial ownership dan leverage. Hal ini sejalan dengan hasil penelitian Kazemian \& Sanusi (2015), yang menemukan bahwa ukuran perusahaan sebagai 'quasi' moderator, dan memiliki hubungan negatif dan signifikan antara tingkat kepemilikan manajemen. Kepemilikan manajerial merupakan mekanisme pemantauan yang efektif, terutama di perusahaan kecil. Mereka menyarankan bahwa kepemilikan manajerial harus didorong di perusahaan kecil sehingga dapat menggantikan kelemahan mekanisme tata kelola perusahaan lainnya. Dapat disimpulkan bahwa kepemilikan manajerial kurang signifikan pada perusahaan berukuran besar dibandingkan dengan perusahaan berukuran kecil (Kazemian \& Sanusi, 2015).

\section{KESIMPULAN DAN SARAN}

Persamaan Regresi menunjukkan hasil uji 2SLS antara nilai perusahaan dengan leverage membuktikan adanya interaksi yang positif signifikan. Sebaliknya hasil uji 2SLS antara managerial ownership dengan leverage membuktikan adanya interaksi yang negatif signifikan. Managerial ownership merupakan faktor untuk penggunaan sumber daya perusahaan yang lebih baik dan mengurangi biaya agensi (Rashid, 2016). Hasil penelitian ini sejalan dengan Jensen dan Meckling (1976) yang menyatakan bahwa hutang perusahaan dan managerial ownership bertindak sebagai solusi untuk mengendalikan konflik agensi dan pada akhirnya akan berpengaruh kepada nilai perusahaan. Utang harus dihentikan pada titik dimana manajer menjadi berkuasa karena kepemilkannya sehingga menimbulkan peluang bagi manajer sehingga hal tersebut perlu didiskusikan lebih lanjut. Sebagai saran penelitian selanjutnya dapat menguji efek non linier dari hubungan antara hutang dengan nilai perusahaan.

\section{Ucapan Terima Kasih}

Terima kasih kepada Lembaga Penelitian dan Pengabdian Kepada Masyarakat (LPPM) Universitas Tarumanagara yang telah mendanai penelitian ini, dengan Surat Perjanjian Pelaksanaan Penelitian Nomor 1451-Int-KLPPM/UNTAR/XI/2020. Terima kasih kepada Fakultas Ekonomi dan Bisnis (FEB) Universitas Tarumanagara yang telah membantu dalam kegiatan administrasi, dan mahasiswa/i FEB Universitas Tarumanagara Jurusan Manajemen 
yaitu Jefferson Indra Gotama dan Jennifer Victoria yang telah membantu dalam melakukan penelitian.

\section{REFERENSI}

Anton, S. G. (2017). The Impact of Leverage on Firm Growth. Empirical Evidence from Romanian Listed Firms. Review of Economic and Business Studies, 18, 147158.https://doi.org/10.1515/rebs-2016-0039

Bamiatzi, V., Efthyvoulou, G., \& Jabbour, L. (2017). Foreign vs domestic ownership on debt reduction: An investigation of acquisition targets in Italy and Spain. International Business Review,25(5), 801-815. https://doi.org/10.1016/j.ibusrev.2017.01.008

Boshkoska, M. (2014). The Agency Problem: Measures for Its Overcoming. International Journal of Business and Management,10(1),204209.https://doi.org/10.5539/ijbm.v10n1p204

Chen, C. R., \& Steiner, T. L. (1999). Managerial ownership and agency conflicts: A nonlinear simultaneous equation analysis of managerial ownership, risk taking, debt policy, and dividend policy. Financial Review, 6(5), 274-284. https://doi.org/10.1111/j.15406288.1999.tb00448.x

Crutchley, C. E., \& Hansen, R. S. (1989). A Test of the Agency Theory of Managerial Ownership, Corporate Leverage, and Corporate Dividends. Financial Management,18(4),36-46.https://doi.org/10.2307/3665795

Ekadjaja, M., Siswanto, H. P., Nuringsih, K., and Amelinda, R. (2019). Parabolic Effect Between Managerial Ownership and Firm Value to Control Agency Conflict. Jurnal Manajemen, 23(3), 355-374. DOI: 10.24912/jm.v23i3.569.

Gujarati, D., \& Gujarati, D. (2015). Panel Data Regression Models. In Econometrics. New York:MC GrawHill. https://doi.org/10.1007/978-1-137-37502-5_17

Hatem, B. S. (2015). Interdependence between Managerial Ownership, Leverage and Firm Value: Theory and Empirical Validation. International Journal of Economics and Finance,7(12),106-118. https://doi.org/10.5539/ijef.v7n12p106

Henny, H., \& Sha, T. L. (2020). Pengaruh Kepemilikan Manajerial Dan Kepemilikan Institusional Terhadap Future Earnings Response Coeficient Dengan Kesempatan Pertumbuhan Sebagai Variabel Moderasi. Jurnal Muara Ilmu Ekonomi Dan Bisnis,4(2),374-383.https://doi.org/10.24912/jmieb.v4i2.7556

Iqbal, A., Zhang, X., Tauni, M. Z., \& Jebran, K. (2020). Principal-principal agency conflicts, product market competition and corporate payout policy in China. Journal of Asia Business Studies,14(3), 265-279. https://doi.org/10.1108/JABS-02-2018-0038

Jensen, N., \& Meckling, W. (1976). Theory of the firm: Managerial behavior, agency costs, and capital structure. Journal of Financial Economics, 3(4), 305-360.

Kazemian, S., \& Sanusi, Z. M. (2015). Earnings Management and Ownership Structure. Procedia Economics and Finance, 31,618-624.https://doi.org/10.1016/s22125671(15)01149-1

Lee, C. F., \& Kuo, N. T. (2014). Effects of ultimate ownership structure and corporate tax on capital structures: Evidence from Taiwan.. International Review of Economics and Finance, 29(C),409-425. https://doi.org/10.1016/j.iref.2013.07.004

Lee, J., \& Chung, K. H. (2018). Foreign ownership and stock market liquidity. International Review of Economics and Finance, 6(1),1-11. https://doi.org/10.1016/j.iref.2017.10.007

Pratama, I., \& Wiksuana, I. (2016). Pengaruh Ukuran Perusahaan Dan Leverage Terhadap Nilai Perusahaan Dengan Profitabilitas Ssebagai Variabel Mediasi. E-Jurnal Manajemen Universitas Udayana,3(1), 30-36.

Puspitowati, Ida, Kartika Nuringsih \& Rita Amelinda.(2018).Defisit Vs Surplus Finansial Dan 
Keterkaitannya Dengan Struktur Modal. Jurnal Muara Ilmu Ekonomi Dan Bisnis,2(1), 204-209.https://doi.org/ 10.24912/jmieb.v2i1.1753

Rashid, A. (2016). Managerial Ownership and Agency Cost: Evidence from Bangladesh. Journal of Business Ethics, 137(3), 609-621 https://doi.org/10.1007/s10551-015-2570-z

Safitri, L. A., \& Wulanditya, P. (2019). Pengaruh kepemilikan institusional, kepemilikan manajerial, profitabilitas, free cash flow, ukuran dan pertumbuhan perusahaan terhadap kebijakan hutang. The Indonesian Accounting Review,7(2), 141154.https://doi.org/10.14414/tiar.v7i2.958

Sinha, P., \& Agnihotri, S. (2015). Impact of non-normal return and market capitalization on estimation of VaR. Journal of Indian Business Research,7(3), 222-242. https://doi.org/10.1108/JIBR-12-2014-0090

Sulong, Z., Gardner, J. C., Hussin, A. H., Sanusi, Z. M., \& Mcgowan, C. B. (2013). Managerial Ownership, Leverage and Audit Quality Impact on Firm Performance:-Evidence From the Malaysian Ace Market. Accounting \& Taxation •. Econ Papers,5(1), 59-70.

Sumartha, E. (2016). Pengaruh Struktur Kepemilikan Terhadap Kebijakan Dividen Pada Perusahaan Manufaktur. Jurnal Economic, 182.https://doi.org/10.21831/economia.v12i2.11114

Susan, M. (2018). Financial behavior and problems among college student in Indonesia: The role of financial knowledge. International Journal of Engineering and Technology(UAE), 7(3), 133-137. https://doi.org/10.14419/ijet.v7i3.25.17531

Susanto, William \& Kartika Nuringsih. (2020). The Parabolic Effect of Managerial Ownership and the Impact Toward Firm's Performance. Jurnal Ekonomi.25(2),233250.https://doi.org/10.24912/je.v25i2.663

Yegon, C., Jane, S., \& Kirui, J. (2014). The Impact of Corporate Governance on Agency Cost: Empirical Analysis of Quoted Services Firms in Kenya ,5(12), 145-154. Research Journal of Finance and Accounting.

Zhang, F., Yang, J., Xu, Z., \& Zhu, G. (2018). Large shareholder participation behaviors, managers' risk-taking and firm innovation performance: A shareholder activism perspective. Nankai Business Review International, 9(1), 99-115 https://doi.org/10.1108/NBRI-04-2017-0017 